\title{
Riggia cryptocularis sp. nov. (Isopoda, Cymothoidae) from the body cavity of a freshwater fish of Mato Grosso do Sul State, Brazil ${ }^{1}$
}

\author{
Vernon E. Thatcher ${ }^{2}$, Luiza Paula de Conceição Lopes $^{3} \&$ Otavio Froehlich ${ }^{3}$
}

\author{
${ }^{1}$ Contribution number 1429 of the Departamento de Zoologia, Universidade Federal do Paraná. \\ 2 Departamento de Zoologia, Universidade Federal do Paraná. Caixa Postal 19020, 81531-980 Curitiba, Paraná, Brasil. \\ Research Fellow of the CNPq. \\ ${ }^{3}$ Departamento de Biologia, Universidade Federal de Mato Grosso do Sul. Caixa Postal 549, 79070-900 Campo Grande, \\ Mato Grosso do Sul, Brasil.
}

\begin{abstract}
Riggia cryptocularis sp. nov. (Isopoda, Cymothoidae) is described on the basis of one female and one male specimen from the body cavity of freshwater fish from Mato Grosso do Sul State, Brazil. The new species is similar in size to $R$. paranensis Szidat, 1948, but differs from that species in the following respects. The body shapes are different since the widest part of the adult female is more anterior in $R$. paranensis. The eyes of the new species are covered and non-functional unlike those of the other species. The cephalon of the new species has a postero-dorsal elevation and a rounded and depressed frons which are lacking in the other species. Pereonites 57 are subequal in length in the new species and decrease in length in $R$. paranensis. The pleon/pleotelson tapers in the female of the new species and in the other it is bluntly rounded and with nearly parallel sides. The pleopods of $R$. cryptocularis sp. nov. also taper while those of $R$. paranensis are rounded. The recently described species, $R$. acuticaudata Thatcher, Lopes \& Froehlich, 2002, was also obtained in Mato Grosso do Sul State but differs greatly from the presently described species. The body of $R$. acuticaudata is much smaller, and more rounded. The eyes of this species are large and functional, the dorsum of the cephalon lacks a dorsal prominence and the pleon/pleotelson tapers more abruptly.
\end{abstract}

KEY WORDS. Brazil, Cymothoidae, fish parasite, isopod parasite, Mato Grosso do Sul.

SZIDAT (1948) described a new genus and species that he called Riggia paranensis found in the body cavity of a freshwater fish of the Paraná River in Argentina. Although similar to Artystone Schioedte, 1866, adult females of his new genus were distinguished by having the pleon and pleotelson fused into a single unit. Later, SzIDAT \& SChubart (1960) added two more species, namely: $R$. nana and $R$. brasiliensis found in freshwater fishes of São Paulo State, Brazil. Bastos \& Thatcher (1997) redescribed the type species based on specimens from Rio de Janeiro State and emended the generic diagnosis. According to Trilles (1991) and Thatcher (2000) only the above three species had been attributed to this genus. Thatcher et al. (2002) described a new species they called Riggia acuticaudata from Mato Grosso do Sul State. The present paper describes an additional new species of Riggia from fishes of Mato Grosso do Sul State, Brazil, which is the fifth in the genus.

\section{MATERIAL AND METHODS}

Fish hosts were netted in small streams in Mato Grosso do Sul State. The cymothoids were removed from the fish and preserved in $70 \%$ alcohol. The appendages of the isopods were removed with dissecting needles and cleared in pure phenol for study in temporary preparations. Permanent slides were made of some mouthparts by use of the phenol-balsam method described in Thatcher (1991). Photographs were taken with a digital camera at five megapixels and drawings were made with a camera lucida. Measurements are in micrometers $(\mu \mathrm{m})$ unless specified as millimeters ( $\mathrm{mm})$.

\section{RESULTS}

Riggia Szidat, 1948, Bastos \& Thatcher, 1997 Riggia cryptocularis sp. nov.

Figs 1-26

Hosts. Ancistrus sp., Loricariidae; Odontostilbe paraguayensis Eigenmann \& Kennedy, 1903, Characidae.

Site: Body cavity. Brazil.

Locality: Piraputanga River, Mato Grosso do Sul State,

Revista Brasileira de Zoologia 20 (2): 285-289, junho 2003 

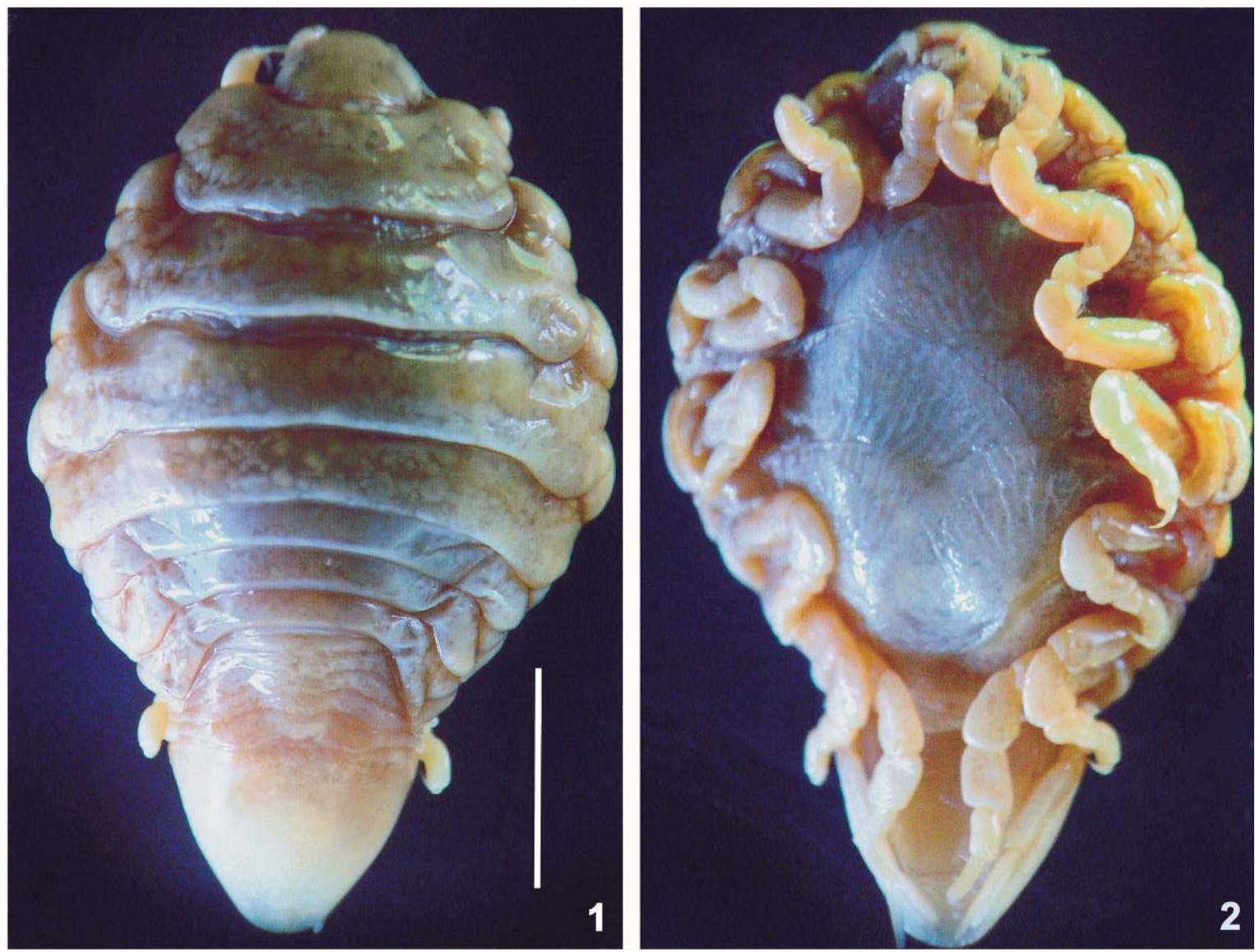

Figures 1-2. Riggia cryptocularis sp. nov., female: (1) dorsal view, (2) ventral view. Scale $=5 \mathrm{~mm}$.

Intensity: 1/fish.

Type material. Holotype female and Alotype male deposited in the Crustacean Collection of the Instituto Nacional de Pesquisas da Amazônia, Manaus, Amazonas, Brazil.

Etymology. The species name is in reference to the hidden eyes.

Species description (based on 1 female and 1 male). Female: body $20 \mathrm{~mm}$ long and $13 \mathrm{~mm}$ wide; pleon/pleotelson 6.5 $\mathrm{mm}$ long and $5.3 \mathrm{~mm}$ wide; body convex dorsally, widest at level of pereonite 3; pereonites 1-3 subequal in length, 4 shorter, 5-7 short and subequal in length (Fig. 1). Cephalon immersed in pereonite 1 ; dorsally concave, frons bluntly rounded; eyes concealed, non-functional (Fig. 3). Antennule slender, shorter than antenna, composed of seven articles (Fig. 8). Antenna slender, of seven articles (Fig. 9). Antennae widely separated at base (Fig. 7). Mouthparts (Figs 10-13): maxilliped with lateral plumose setae, palp with two small terminal spines; maxillule with ending in five recurved spines with three being terminal and two being subterminal; maxilla bilobed terminally with 1 stout spine on each lobe; mandible slender with few small spines terminally, palp of three articles, shorter than mandible. Pereopods (Figs 15-21): 1-6 terminating in small claw-like dactyls, $7^{\text {th }}$ dactyl simple. Pleon and pleotelson fused, immersed in pereonite 7; pleotelson tapered, posteriorly rounded (Fig. 1). Pleopods (Figs 22-26) tapered, bilaminate excep for two which is trilaminate, the endopod being bilaminate; endopods smaller than exopods. Uropod (Fig. 14) with elongate, slender rami, exopod longer than endopod.

Male (Figs 4-5): Body small, $4.94 \mathrm{~mm}$ long and $2.3 \mathrm{~mm}$ wide; pleon and pleotelson not fused together, measure $2.2 \mathrm{~mm}$ long and $1.5 \mathrm{~mm}$ wide. Cephalon not immersed in pleonite 1 ; eyes concealed, non-functional (figure 4 shows the eyes hidden under an outer cuticle; figure 5 shows a specimen cleared in pure phenol in which the eyes are visible). Pleon not immersed in pereonite 7 , tapers slightly in direction of pleotelson; latter shield-shaped terminating in sharp point. Uropodal rami less slender than in female and provided with marginal setae.

\section{DISCUSSION}

In terms of size, the female of Riggia cryptocularis sp. nov. is most similar to $R$. paranensis which has been reported to be 14-28 mm long and 10-20 mm wide (BASTOS \& THATCHER, 1997). $R$. brasiliensis is larger, $33 \times 28 \mathrm{~mm}$ and $R$. nana smaller, $14 \mathrm{x}$ 

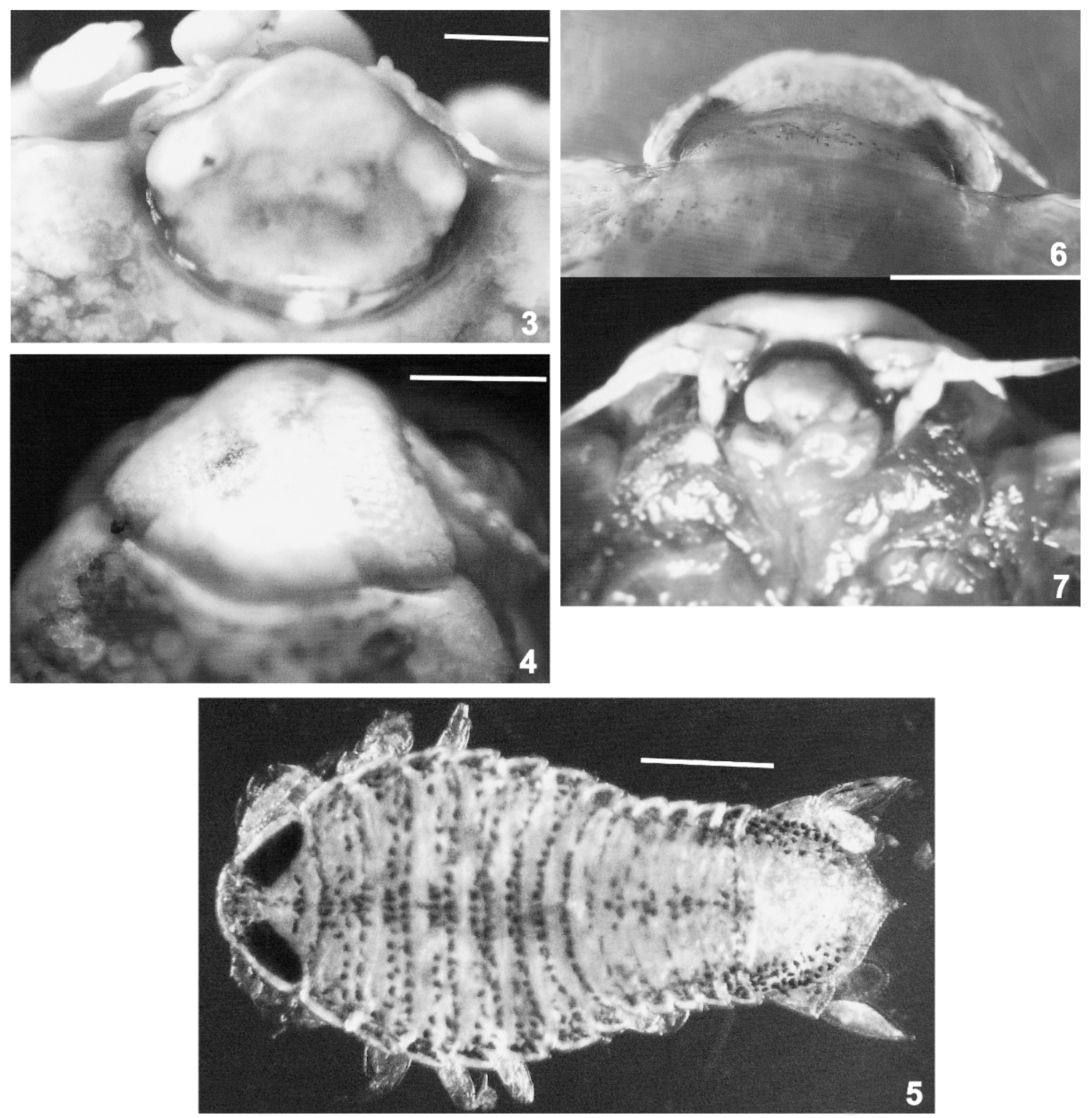

Figures 3-7. Riggia cryptocularis sp. nov. (3-4) Cephalons, dorsal views: (3) female, (4) male; (5) male, dorsal view of cleared specimen showing hidden eyes revealed; (6-7) female: (6) dorsal view of cleared cephalon showing hidden eyes revealed; (7) ventral view of cephalon showing antennae and mouthparts. Scales: 3 and $5=1000 \mu \mathrm{m}, 4=500 \mathrm{~mm}, 6$ and $7=2 \mathrm{~mm}$.

$10 \mathrm{~mm}$, according to SzIDAT \& SCHUbart (1960). The new species differs from $R$. paranensis in a number of respects: 1 ) the body shape is different because $R$. paranensis has its greatest width closer to the cephalon; 2 ) the eyes of $R$. paranensis are prominent and functional while in the new species they are covered; 3 ) in the new species, pereonites 5-7 are subequal in length whereas in the other species these segments decrease in length from 5 to $7 ; 4)$ the pleon/pleotelson tapers in the new species whereas in the other species this structure is bluntly rounded posteriorly and has nearly parallel sides; 5 ) the pleopods of the new species also taper more than those of $R$. paranensis; 6 ) the cephalon of the new species has a postero-dorsal elevation and a broad, depressed frons that are lacking in the other known species. $R$. acuticaudata, recently described by THAтсHER et al. (2002) from fishes of Mato Grosso do Sul State is small and round (11$16 \mathrm{~mm}$ ), has prominent eyes, lacks a postero-dorsal elevation

Revista Brasileira de Zoologia 20 (2): 285-289, junho 2003 


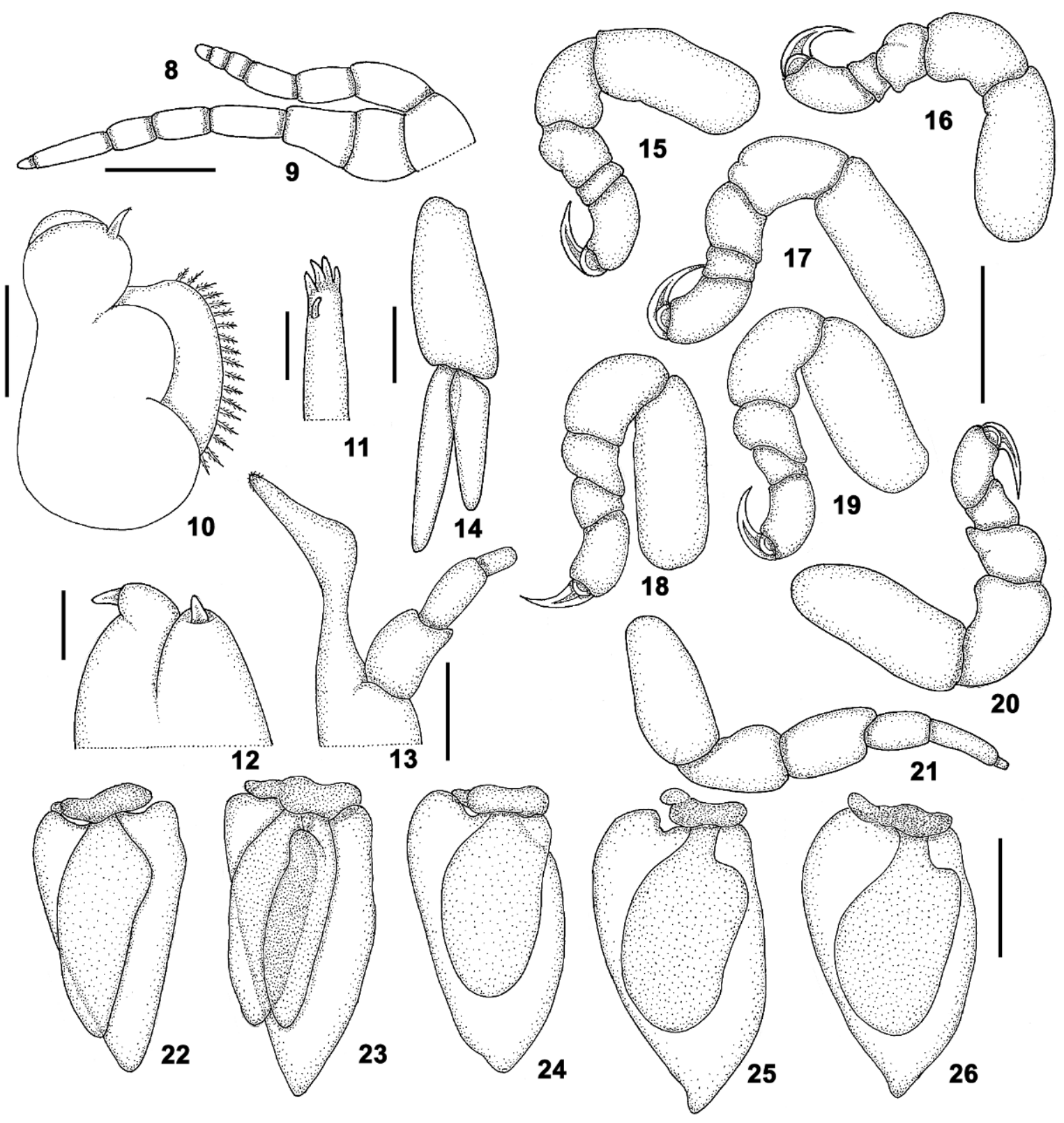

Figures 8-26. Riggia cryptocularis sp. nov., female: (8) antennule (9) antenna (10) maxilliped (11) maxillule (12) maxilla (13) mandible and palp, (14) uropod, (15-21) pereopods 1-7, (22-26) pleopods 1-5. Scales: 8, 9 and $13=500 \mu \mathrm{m}, 10$ and $14=1000 \mu \mathrm{m}, 11$ and 12 $=100 \mu \mathrm{m}, 15-26=2 \mathrm{~mm}$.

on the cephalon and has a more tapered pleon/pleotelson than the new species.

SZIDAT \& SCHUBART (1960) reported that R. paranensis has a dwarf male that measures slightly more than $5 \mathrm{~mm}$ in length. BASTOS \& THATCHER (1997) were able to confirm this observation. Perhaps all species of Riggia have dwarf males since the male of the new species also measured around $5 \mathrm{~mm}$ in length. Apparently, the tiny male visits and impregnates the femsle after she has penetrated a host fish and then disappears. This would explain why the males have seldom been found. In the case of the male described here, the eyes are also covered and the cephalon is similar to that of the female.

Revista Brasileira de Zoologia 20 (2): 285-289, junho 2003 
Covered eyes have sometimes been observed in marine Cymothoidae but not previously in freshwater species. The cause or significance of hidden eyes is unknown but a possible explanation would be that they sometimes have trouble moulting and the old cuticle remains and hides the eyes either temporarily or permanently. Covered eyes of the female and male respectively are shown in figures 3 and 4 . By clearing the specimens in phenol, it was possible to verify that both sexes have eyes under a heavy cuticle (Figs 5 and 6).

The female specimen was found in a loricariid catfish, Ancistrus sp., and the male in a characid, Odontostilbe paraguayensis. The latter may be an accidental host since that species is too small to house a mature female of $R$. cryptocularis sp. nov.

\section{REFERENCES}

Bastos, P.B. \& V.E. Thatcher. 1997. A redescription of Riggia paranensis Szidat, 1948 (Isopoda, Cymothoidae) based on thirty-two specimens from curimatid fish of Rio de Janeiro, Brazil, with an emendation of the genus. Memórias do Instituto Oswaldo Cruz, Rio de Janeiro, 92: 755-760.

SzIDAT, L. 1948. Riggia paranensis n.g., n. sp., un isópodo parásito de la cavidad del cuerpo de "Curimata pistana" Günther, del Rio Paraná. Revista del Instituto de Investigación de las Ciencias Naturales Ciencias Zoológicas, Buenos Aires, 1 (2): 45-56.

Szidat, L. \& O. Schubart. 1960. Neue und seltene parasitische süswasser-Asseln der familie Cymothoidae aus dem Rio Mogi Guassu, Brasilien (Isopoda). Annais da Academia brasileira da Ciência, Rio de Janeiro, 32: 107-124.

Thatcher, V.E. 1991. Amazon fish parasites. Amazoniana, Ploen, 11: $263-572$.

. 2000. The isopod parasites of South American fishes, p. 193-226. In: G. Salgado-Maldonado; A.N. Garcia-Aldrete \& V.M. Vidal-Martínez (Eds). Metazoan Parasites in the Neotropics. México, D.F., Universidad Nacional Autónoma de México Press, 310p.

Thatcher, V.E.; L.P.C. Lopes \& O. Froehlich. 2002. Riggia acuticaudata sp. n. (Isopoda, Cymothoidae) from the body cavity of a freshwater fish of Mato Grosso do Sul State, Brazil. Revista brasileira de Zoologia 19 (Supl. 2): 195-201.

Trilles, J.P. 1991. Catalogue mondial dês Cymothoidae. Studia Marina, Kotor, 21/22 (1-2): 5-288.

Received in 25.XI.2002; accepted in 27.V.2003.

Revista Brasileira de Zoologia 20 (2): 285-289, junho 2003 